\title{
KULTURA LUDOWA NA LEKCJACH JEZYYKA POLSKIEGO WŚRÓD DZIECI POLSKIEJ EMIGRACJI W SZKOCJI
}

\author{
SŁowa KLUCZOWE: KUlTURA LUdOWA, EDUKACJA POLONIJNA, WSPÓLNOTA
}

Myślę, że gdybym miat dzieci, chciałbym, żeby wiedziały, kim sa, skąd pochodza, miaty świadomość swoich korzeni. By nie wstydzity się tego. Ale nie starałbym się ich izolować

[Polak żyjący w Edynburgu od 2010 r.]

\section{WSTĘP}

Artykuł prezentuje rezultaty projektu edukacyjnego przeprowadzonego w środowisku polskich emigrantów w miasteczku Kirkcaldy w roku szkolnym 2011-20121. Badania prowadzone z perspektywy nauczyciela języka polskiego i antropologa z użyciem metod etnograficznych: obserwacji, partycypacji, etnografii wizualnej i sensorycznej pozwoliły na zebranie spostrzeżeń dotyczących różnorodnych zastosowań kultury ludowej na zajęciach w Polskiej Szkole Sobotniej.

${ }^{1}$ Rosnąca liczba Polskich Szkół Sobotnich w Szkocji to rezultat intensywnych procesów migracji Polaków do Wielkiej Brytanii od momentu przyjęcia do Unii Europejskiej - wpływa na spójność lokalnej polskiej diaspory tworząc wielorakie przestrzenie dla wyrażania, ubogacania i negocjowania tożsamości. Liczba polskich rezydentów w Szkocji nieustannie rośnie. W 2012 r. szacowano, że liczba Polaków wynosiła około 56000 osób [Piętka-Nykaza, McGhee 2014: 1], późniejsze badania wskazywały, że wynosi 61000 [Martowicz, Roach 2014: 2], a obecnie może sięgać nawet 100000 [Bukalska 2016: 12]. Pracujący w różnych branżach Polacy często decydują się sprowadzić swoje rodziny do siebie i zacząć nowe życie w Szkocji, co w rezultacie skutkuje rosnącą liczbą polsko mówiących dzieci w szkockich klasach. Wedle raportu rządowego w szkockim szkolnictwie podstawowym, średnim, w szkołach specjalnych i przedszkolach, liczba uczniów pochodzenia polskiego szacowana jest na 11 863, co stanowi 1,76\% wszystkich szkockich uczniów - 672240 [Martowicz, Roach 2014: 2-8]. Do strategii szkół szkockich wspierających edukację i integrację dzieci emigrantów zaliczyć można organizację dodatkowych lekcji z języka ojczystego lub zatrudnienie asystenta nauczyciela mówiącego w języku polskim (osoba dorosła, która wspiera w klasie nauczyciela wiodącego) [Moskal 2010: 4]. Obecne inicjatywy zarówno środowisk naukowych, jak i rządu szkockiego zmierzają do wprowadzenia planu włączającego język polski do programu szkolnego, co w przyszłości pozwoli dzieciom na zdawanie języka polskiego na poziomie A w egzaminie GCSE (brytyjski odpowiednik polskiej matury) [Polish Language 2015]. 
Obecnie w Szkocji jest 17 Polskich Szkół Sobotnich ${ }^{2}$ (m.in. w Edynburgu, Glasgow, Aberdeen, Inverness, Kirkcaldy, Motherwell), w których uczy się około 1300 uczniów na cotygodniowych zajęciach po 3-4 godziny. Stanowią one dodatkowy program edukacyjny uzupełniający oficjalną podstawę programową szkół szkockich. Nomenklatura stosowana przez Martowicz i Roach [2014: 12] określająca uczniów jako „Szkotów polskiego pochodzenia” nie oddaje skomplikowanej natury formującej się tożsamości wśród dzieci z rodzin polskich. Niektóre z nich przybyły do Szkocji po krótkim doświadczeniu w polskim systemie edukacji; inne, urodzone w Polsce, będą w Szkocji przez krótki okres ze swoimi rodzicami i po kilku czy kilkunastu miesiącach powrócą do Polski, by kontynuować edukację w szkołach podstawowych i średnich. Jest także grupa dzieci urodzonych w Szkocji, które po paru latach w tutejszych przedszkolach czy szkołach podstawowych powrócą do polskiego systemu edukacji. Dla nich wszystkich tożsamość szkocko-polska jest w tym momencie tymczasowa, kształtowana w szczególnym czasie i przestrzeni, w której żyją. Co więcej, jest płynna i podatna na formowanie - po powrocie do Polski na stałe zminiaturyzowana stanie się epizodem w biografii; lub też, jeśli dzieci zostaną w Szkocji, będzie systematycznie rozwijana, zaś rozumienie polskości ograniczone będzie z czasem do dziedzictwa przodków. Ta sytuacja oznacza, że dzieci reprezentują grupę osób określanych w literaturze jako circumstancial bilinguals [Chin, Wigglesworth 2007: 21]. W okolicznościach, w których się znalazły, znajomość języka angielskiego jest niezbędna, by sprostać nowym okolicznościom, a rozwój zdolności komunikacyjnych umożliwia przetrwanie, a nawet sukces. Stawiać to może język polski w gorszej pozycji, a w skrajnych przypadkach prowadzić nawet do całkowitego zaniechania posługiwania się nim. Podtrzymanie znajomości języka polskiego jako dziedziczonego i skuteczne angażowanie w jego rozwój to warunek dwujęzyczności w warunkach dominacji języka angielskiego, którym posługuje się otoczenie.

Polska Szkoła Sobotnia w miasteczku Kirkcaldy położonym na wschodnim wybrzeżu Szkocji zlokalizowana jest w miejscu o szczególnym znaczeniu dla polskiej powojennej historii w Wielkiej Brytanii. Położenie szkoły tworzy historyczny kontekst $^{3}$ dla nauczania i uczenia się, jak również osadza polską tożsamość w symbolicznej przestrzeni. Budynek szkoły należał do polskiej społeczności w Szkocji od 1965 r., kiedy to zakupili go byli żołnierze Armii Andersa na potrzeby spotkań swojej diaspory, dla podtrzymania języka, kultury i tożsamości [Polska Szkoła 2016]. W 1978 r. odsłonięty został pomnik upamiętniający masakrę katyńską, zaś w latach 90. w budynku SPK aktywna była szkoła języka polskiego. Polska Szkoła Sobotnia w Kirkcaldy została oficjalnie otwarta w 2011 r. i w tym roku świętuje pięciolecie

${ }^{2}$ Na terytorium Wielkiej Brytanii jest ponad 150 Polskich Szkół Sobotnich [Zechenter 2015: 87].

${ }^{3}$ Ogłoszony niedawno konkurs „Opowiedz mi o swojej Szkocji - List do Niedźwiedzia Wojtka” wykorzystywał symbol polskiej powojennej historii w Szkocji, niedźwiedzia Wojtka towarzyszącego przemieszczającym się z armią żołnierzom, którzy ostatecznie dotarli do Wielkiej Brytanii. Wojtek zakończył swoje życie w zoo w Edynburgu, stając się inspiracją m.in. dla pisarzy i artystów teatralnych. Pomnik Niedźwiedzia Wojtka postawiony w 2015 r. w parku Priness Gardens w Edynburgu łączy historię poprzednich i obecnych pokoleń Polaków oraz podkreśla relacje polsko-szkockie. 
aktywności połączonej z dawną historią miejsca stworzonego przez byłych polskich żołnierzy i emigrantów czasów socjalizmu.

Warunki egzystencji we współczesnym kontekście szkockim, a szerzej brytyjskim, prowadzą do refleksji nad statusem języka polskiego wśród polskiej społeczności i jej potomstwa, korzyści z nauczania języka dziedziczonego dla komunikacji i spójności między pokoleniami, wzbogacenia kulturowego, sposobów, w jaki językowa tożsamość kształtuje się i przeformowuje pod wpływem różnych czynników. Poloniści, podkreślając zalety dwujęzyczności, tworzą materiały edukacyjne dla rodziców [Martowicz 2014; Nott-Bower 2016] oraz organizują warsztaty metodyczne, konsultacje i konferencje [Polska Macierz Szkolna 2016; Wspólnota Polska 2016]. Programy Polskich Szkół Sobotnich zwracają szczególną uwagę na tematykę zwyczajów rodzinnych i dorocznych tradycji, takich jak np. Święta Bożego Narodzenia, Nowy Rok, Wielkanoc, Noc Świętego Jana, Dzień Wszystkich Świętych, Andrzejki. Tu wiedza o kulturze polskiej splata się z tematyką kultury ludowej i przez jej pryzmat może być prezentowana, np. w formie jasełek, zabaw sobótkowych czy wróżb andrzejkowych, jak również warsztatów plastycznych - dotyczących tradycyjnych ozdób choinkowych, palm wielkanocnych czy pisanek. Polscy etnografowie proponują wykorzystanie kultury ludowej na lekcjach języka polskiego celem ukazania uczniowi kontekstów kultury regionalnej, a co za tym idzie okoliczności powstawania niektórych utworów literackich [Ludowe Okulary 2016; Z Wiejskiego Ogródka 2016; Sołtan 2012].

\section{KONTEKST KULTURY LUDOWEJ NA LEKCJACH JĘZYKA POLSKIEGO}

Aktywne uczestnictwo w zajęciach szkoły polonijnej to doskonalenie umiejętności językowych, rozwijanie ekspresji twórczej, pobudzanie do współdziałania w grupie i do indywidualnej aktywności. Jest to także doświadczenie wspólnotowe, tworzące nowe relacje wewnątrz polskiej diaspory, zapełniające przestrzenie życia rodzinnego i towarzyskiego. Doświadczenie to łączy się z cechami kultury ludowej, do których należą: tradycjonalizm rozumiany jako ustny przekaz umiejętności, wiedzy, przekonań między pokoleniami; religijność i jej manifestacje; myślenie mityczne, doświadczanie świata w sposób inny niż empiryczny [Sołtan 2012: 7] $]^{4}$.

Kultura ludowa to także „ogół wytworów, wartości i znaczeń wypracowanych (...) w ramach społeczności wiejskich" [Bukraba-Rylska 2002: 1]. Jest to część dziedzictwa kulturowego, które ,akumuluje i przechowuje” owe wytwory, wartości i znaczenia, a zatem edukacja młodych pokoleń w zakresie kultury ludowej stanowi o trwaniu dziedzictwa zbudowanego na wartościach intelektualnych, moralnych, społecznych, religijnych czy estetycznych [Niematerialne dziedzictwo kulturowe 2016: 5]. Ponadto

${ }^{4}$ Działania podejmowane w celu podtrzymania wiedzy o religii katolickiej i jej tradycjach stanowią odrębny przykład międzypokoleniowego ustnego przekazu. Wiedza o religii katolickiej i dla niektórych dzieci przygotowanie do Pierwszej Komunii i sakramentu Spowiedzi były organizowane przez rodziców dodatkowo po lekcjach. Podtrzymywanie kultury duchowej rodzin wyznania katolickiego i uczestnictwo w życiu religijnym to budowanie kolejnej sfery odniesień w językowo-kulturowym rozwoju dziecka. 
(...) kultura ludowa to specyficzna subkultura kultury współczesnej (żywej kultury). Składają się na nią konfiguracje praktyk kulturalnych oraz ich materialnych i niematerialnych wytworów. Kultura ludowa istnieje w perspektywie glokalizacyjnej [rozumianej jako połączenie lokalnego z globalnym - dopisek A.Sz.], która zbiega się w każdym konkretnym wypadku w punkcie oznaczonym jako SWOJSKOŚĆ. [Fatyga 2014: 415].

Podejmując się próby zdefiniowania roli kultury ludowej na lekcjach języka polskiego, należy uwzględnić zarówno kulturę materialną (np. pisanka z Zalipia), jak również przejawy niematerialnego dziedzictwa kulturowego, takie jak zwyczaje, rytuały, obrzędy świąteczne czy też umiejętności związane z rzemiosłem tradycyjnym (np. celebrowanie Nocy Świętojańskiej czy tworzenie palmy wielkanocnej z bibułkowych kwiatów i gałązek). Należy też pamiętać, że to system symboliczno-religijny stanowi o charakterze duchowej i materialnej kultury ludowej, czego wyrazem jest plastyka obrzędowa [Sztych 2008: 46], na przykład postać turonia w jasełkach. Wykorzystując walory i zasoby kultury ludowej w nauczaniu polonijnym, należy przypomnieć uczniom, że wynikają one z historii i etnografii danego regionu. Choć kultura ludowa wytwarzana w dzisiejszej Polsce przez twórców ludowych jest kreowana w większości na potrzeby zewnętrznych odbiorców (np. na festiwale, pokazy w skansenach, kiermasze rękodzieła), nie zaś lokalnej społeczności, jak to miało miejsce dawniej [Mokras-Grabowska 2013: 48], nadal silnie zaznacza się jej związek z miejscowymi tradycjami.

Jedną z cech kultury ludowej jest według Dobrowolskiego „trwałość tradycyjnego zasobu motywów, wątków, kształtów, ornamentów, wzorów i barw" [Bukraba-Rylska 2002: 4], z których korzystają ludowi rzemieślnicy i artyści. Dla potrzeb edukacyjnych korzysta się z elementów kultury ludowej autentycznej (np. zdobiona wzorem zalipiańskim pisanka wielkanocna informuje nie tylko o świątecznej tradycji, ale też o tradycjach wioski Zalipie; jaja barwione przez gotowanie wraz z łupinami cebuli, a następnie skrobane we wzorki informują o technice wyrobu - drapaniu, skrobaniu) i nieautentycznej (ograniczenie się do zastosowania naklejek kupionych w sklepie, które imitują pseudoludowe wzory, np. z regionu Łowicza, nie wskazują jednak na technikę wykonania, nie angażują w proces kreowania). Upraszczanie i schematyzowanie wiedzy na lekcjach powinno ograniczać się do minimum, jako że dla wielu dzieci rzeczywistość, w której żyją, a dodatkowo często pozostające ze sobą bez korelacji przestrzenie dwujęzyczności, w konsekwencji prowadzą do braków w elementarnej wiedzy i błędnej interpretacji rzeczywistości ${ }^{5}$.

Sobotnie spotkania w polskiej wspólnocie dzieci z rodzin emigrantów stawiały przed nauczycielem polonistą problem wyboru ze złożoności i lokalności ludowych tradycji w stosunku do grupy różnorodnej pod względem pochodzenia regionalnego (tab. 1), aby podejmowane strategie nauczania były skuteczne, a jednocześnie nie ograniczały się do tradycyjnego schematu „krakowiaków i górali”, czyli folkloru okolic Krakowa i Zakopanego [Roter-Bourkane 2015]. W środowisku polonijnej

${ }^{5}$ Wskazują na to wypowiedzi uczniów: „Banany rosną w Szkocji” [bo można je kupić w supermarkecie], „Mleko pochodzi ze sklepu” [brak wiedzy o krowie wytwarzającej mleko, jej wizerunku nie ma też na opakowaniu mleka]. 
edukacji poczucie odrębności regionalnej zaciera się. Ograniczenia czasowe w ciągu roku szkolnego sprawiają, iż nauczyciele opierają się na schemacie Warszawa - stolica, Kraków - historia i kultura, Zakopane - góry, Gdańsk - Morze Bałtyckie, pomniejszając znaczenie regionów etnograficznych, których dzięki zróżnicowaniu wytworów kultury ludowej można wydzielić co najmniej 6: wielkopolski, śląski, małopolski, sieradzki, mazowiecki, pomorski [Bukraba-Rylska 2002: 5]. Czerpanie z kultury ludowej podczas lekcji pokazuje tę różnorakość, co pozwala znacznie rozbudować schematycznie konstruowaną na podstawie historii i atrakcyjności krain geograficznych oś - Północ-Centrum-Południe. Natalia Anzulewicz, analizując alternatywne programy edukacyjne realizowane w polskich szkołach sobotnich, podkreśla z kolei konieczność dialogu międzykulturowego, co pozwoli „zachować to, co nam bliskie, nie negując tego, co obce" [2014: 264]. W praktyce oznacza to selekcję nauczanego materiału i układ paraleli pokazujący zróżnicowanie kultury ludowej na przykładzie dwóch narodów (tab. 2). Kultura ludowa stanowi kontekst pozwalający łączyć różne zjawiska i wyjaśniać świat przez analogię. Kontekstowi rozumianemu jako tło interpretacyjne dzieła przypisać można dwie podstawowe wartości: psychologiczną - „inspirowanie do skupienia uwagi”, „działania zmierzające do usuwania poczucia obcości" w stosunku do dzieła, oraz merytoryczną - dostarczenie informacji [Bobiński 2004: 224]. Wykorzystując te wartości w odniesieniu do nauki języka dziedziczonego, wprowadzanie kultury ludowej usprawnia procesy przyswajania języka. Kontakt z dziedzictwem w formie muzyki, zajęć ruchowych i plastycznych wspiera rozwój pozajęzykowych kompetencji komunikacyjnych.

TABela 1. Pochodzenie, WieK, CZas Pobytu w SzKocji I dośWiadczenie JĘZYKA DZIECI W GRUPIE 6-8 LAT

\begin{tabular}{|l|c|l|l|l|l|}
\hline $\begin{array}{c}\text { Pochodzenie } \\
\text { ucznia }\end{array}$ & Wiek & $\begin{array}{c}\text { Data przyjęcia } \\
\text { do szkoły } \\
\text { w Kirkcaldy }\end{array}$ & \multicolumn{1}{|c|}{$\begin{array}{c}\text { Czas pobytu } \\
\text { w Szkocji }\end{array}$} & $\begin{array}{c}\text { Poziom naucza- } \\
\text { nia w szkole } \\
\text { szkockiej }\end{array}$ & $\begin{array}{c}\text { Poziom naucza- } \\
\text { nia w szkole } \\
\text { polskiej }\end{array}$ \\
\hline Wrocław & 8 & 03.2012 & 5 miesięcy & III klasa & I i II klasa \\
\hline Tarnów & 8 & 09.2011 & 2 lata & IV klasa & - \\
\hline Gdańsk & 8 & 09.2011 & 2 lata & IV klasa & - \\
\hline Bolesławiec & 8 & 09.2011 & 5 lat & III klasa & - \\
\hline Poznań i Słupsk & 7 & 09.2011 & $4-5$ lat & III klasa & - \\
\hline Toruń & 7 & 09.2011 & 4 lata & III klasa & - \\
\hline Wolsztyn & 7 & 02.2012 & 2 lata & III klasa & - \\
\hline Warszawa & 6,5 & 11.2011 & 2 lata & II klasa & - \\
\hline Augustów & 6,5 & 04.2012 & 8 miesięcy & II klasa & - \\
\hline
\end{tabular}

ŻRÓDŁO: OPRACOWANIE WŁASNE 2011-2012 R.

W przypadku, gdy uczniami klasy są w większości uczniowie, których rodzice pochodzą z małych miejscowości i wsi, nawiązywanie do wytworów i wartości wypracowanych przez pokolenia w tych środowiskach nabiera szczególnego znaczenia. Usprawnia nie tylko procesy zrozumienia języka dziedziczonego - zbliża również do środowiska krewnych w Polsce, dziadków, nie mówiąc o wsparciu więzi z najbliższą rodziną na emigracji. 
TABELA 2. PRZYKŁADY POLSKO-SZKOCKICH PARALELI MOŻLIWYCH DO WYKORZYSTANIA PODCZAS LEKCJI JĘZYKA POLSKIEGO

\begin{tabular}{|l|l|l|l|l|l|}
\cline { 2 - 6 } \multicolumn{1}{c|}{} & Legendy & $\begin{array}{c}\text { Zwyczaje } \\
\text { wielkanocne }\end{array}$ & Przedmioty & $\begin{array}{c}\text { Tradycyjne } \\
\text { stroje } \\
\text { góralskie }\end{array}$ & \multicolumn{1}{c|}{$\begin{array}{c}\text { Zajęcia } \\
\text { ruchowe }\end{array}$} \\
\hline Polska & $\begin{array}{l}\text { Smok } \\
\text { Wawelski }\end{array}$ & $\begin{array}{l}\text { Malowanie } \\
\text { pisanek }\end{array}$ & Gęśliki & $\begin{array}{l}\text { Strój górala } \\
\text { z Zakopanego }\end{array}$ & $\begin{array}{l}\text { Tańce } \\
\text { Podhala }\end{array}$ \\
\hline Szkocja & $\begin{array}{l}\text { Potwór } \\
\text { z Loch Ness }\end{array}$ & $\begin{array}{l}\text { Turlanie jajek } \\
\text { z pagórków }\end{array}$ & Dudy & $\begin{array}{l}\text { Strój Szkotów } \\
\text { z Pogórza }\end{array}$ & $\begin{array}{l}\text { Tańce Szkoc- } \\
\text { kiego Pogórza }\end{array}$ \\
\hline
\end{tabular}

ŹRÓDŁO: OPRACOWANIE WEASNE 2011-2012 R.

\section{ZACIEKAWIĆ, ZADZIWIĆ, WYZWOLIĆ SKOJARZENIA I KREATYWNOŚĆ} - WARSZTATY TRADYCYJNYCH PALM WIELKANOCNYCH

Przykładem na angażowanie w przebieg lekcji i rozwój sprawności dzięki wykorzystaniu zasobów kultury ludowej były warsztaty wielkanocne (zdj. 1). Autentyczne wykorzystanie plastyki obrzędowej - przygotowanie palm wielkanocnych to po pierwsze prezentacja regionalnych tradycji bibułkarskich, wythumaczenie ich szerszego zastosowania oraz pokaz wytwarzania kolorowych ozdób; po drugie zaś przygotowanie samej palmy ze świeżych gałązek, dekorowanie jej wykonanymi przez siebie kwiatami i wstążkami. Komponowaniu palmy towarzyszyło wyjaśnienie obrzędu Niedzieli Palmowej, jej znaczenia w kontekście religijnym przez etnografa Dorotę Niczke ze Śląska. Kontakt z żywym polskim językiem, dodatkowo o zabarwieniu gwarowym, był atrakcją dla dzieci i umożliwił im ćwiczenie sprawności rozumienia ze słuchu i mówienia.

Wskazując na polski i szkocki wymiar tradycji wielkanocnych, uwzględniono także prezentację szkockich zwyczajów, takich jak palemki w kształcie krzyża z palmowych liści, czy też toczenie jajek ze wzniesień. Transferowanie kapitału kulturowego [Moskal 2016] z Polski do Szkocji było okazją do ćwiczenia praktycznych umiejętności manualnych i gry wyobraźni w tworzeniu ludowego rękodzieła (palmy wykonane były z elementów pochodzących ze szkockiej roślinności, drzew, krzewów, roślin, a dekorowane ręcznie wykonanymi kwiatami z bibuły wykonanymi według instrukcji z książek na temat polskich tradycji ludowych). Zaletą spotkań przez działanie, o których szerzej pisałam w nawiązaniu do warsztatów polskiej koronki dla kobiet w Edynburgu [Sznajder 2013], jest to, że w procesie wspólnego wytwarzania powstaje konkretna rzecz - pełni ona określoną funkcję, np. dekoracyjną czy religijną.

\section{WYWOŁAĆ EMOCJE, WSPIERAĆ DOŚWIADCZENIE WSPÓLNOTY - OBCHODY NOCY ŚWIĘTOJAŃSKIEJ}

Rekonstruowanie zjawisk rodzimego folkloru, takichjak Noc Świętojańska(zdj. 2) jest przykładem na podtrzymywanie i kultywowanie tradycji w środowiskach polonijnych. Spontaniczność, naturalność, prostota, szczerość, a zarazem symboliczność 
rekonstruowanego świata ludowego obrzędu włączyły dzieci w uczestnictwo w rytuał obecny w kulturach narodów słowiańskich. Wspólny żywiołowy taniec w kręgu wokół ogniska wykonywany w rytmie muzyki folkowej („Pieśń Sobótkowa” - Orkiestra św. Mikołaja), w barwnych wiankach na głowach, połączony ze składaniem gałązek i kwiatów oraz wieńców ze świecami na środku sceny, a następnie włączenie do tanecznego korowodu rodziców i przyjaciół uwieńczył całoroczną pracę dzieci. Całość przedstawienia finalizowało poszukiwanie kwiatu paproci w szkole i okolicach oraz nagroda dla znalazcy.

$\mathrm{Z}$ antropologicznego punktu widzenia zabawa w stylizowany słowiański rytuał to przejaw przekazu tradycji, gdzie uczestnicy obrzędu przez symboliczne odtworzenie Nocy Świętojańskiej włączają się w szersze konteksty czasu i przestrzeni, odtwarzając działanie zamykające pewien cykl związany z porą roku, dla nich samych związany z rozpoczęciem wakacji. Przekaz kulturowy, który dokonuje się przez uczestnictwo w obrzędzie, we wspólnocie wyobrażonej tańcem kręgu i dynamiką rytmicznej melodii umożliwia pewien sposób przeżywania kultury, który być może stanowić będzie klucz do zrozumienia innych współczesnych wydarzeń kulturalnych (np. imprezy „Wianki” w Krakowie nad Wisłą). Wedle badań muzyka na żywo oraz taniec uczone przez interakcję z rodzicami i wychowawcami (nie zaś biernie oglądane w telewizji czy odsłuchiwane z komputera) mają szczególną wagę dla rozwoju dwujęzyczności w dzieciństwie [Stochnioł 2015: 42]. Ich rola to, oprócz ochrony i rozwoju tożsamości, kultury i języka, również budowanie związków z rodziną, społecznością, rówieśnikami.

\section{W SIECI KULTUROWYCH ZNACZEŃ - BAŚNIE, ŚPIEW, MUZYKA}

„Noc Świętojańska” odbywała się podczas Festynu „Sami Swoi” - wydarzenia, które podsumowało całoroczną działalność szkoły, gromadząc dzieci, rodziców i lokalną polsko-szkocką społeczność. Zapoczątkowany w czerwcu 2012 r. rodzinny festyn w ciągu kilku lat rozwinął swoją formę do wydarzenia celebrującego przyjaźń polsko-szkocką, pozostając jednakże w ścisłym związku z pierwotną ideą polskiego dnia kultury. Prezentacje polskich pieśni i piosenek, tańce do rodzimych melodii, przedstawienia na temat tradycyjnych zwyczajów czy znanych legend, gry rodzinne, konkursy i zawody, spotkania z zaproszonymi gośćmi (pisarzami, malarzami) z Polski były uzupełnione prezentacjami kultury szkockiej, np. tańcami Szkockiego Pogórza czy koncertami dudziarzy - stwarzając przestrzeń uczestnictwa dla rdzennej szkockiej społeczności lub tej o polskich korzeniach.

Spotkanie autorskie z gościem festiwalu, pisarzem i poetą Andrzejem Grabowskim z małego miasteczka Ciężkowice (Małopolska) prezentującym uczniom Polskiej Szkoły Sobotniej w Kirkcaldy swoją książkę Przygody Skrzata Wiercipiętka ${ }^{6}$ (zdj. 3) wprowadziło w świat baśni osadzonej w rodzimych czasowo-przestrzennych

${ }^{6}$ W 2016 r. ukazał się przekład Przygód Skrzata Wiercipiętka na język angielski w przekładzie Marcela Weylanda. Kolejny etap - wydanie książki po polsku i angielsku - to możliwość wygenerowania dwujęzycznej przestrzeni językowej, która wspierać będzie edukację literacką dzieci. 
realiach, nawiązując za pośrednictwem języka literackiego do szerokiej tradycji gatunku reprezentowanego choćby przez Marię Konopnicką:

Skrzat Borówka, o dużym okrąglutkim nosie, twierdził, że czas już zrobić wiosenny spis ptaków. Czaruś Duży - największy i najsilniejszy w gronie - wołał, że najwyższa pora, żeby siać grzybnie, bo w ubiegłym roku było mało grzybów. Ktoś inny przypominał o szczepieniu rybek w strumyku i budowie żłobka dla ślimaków. A skrzat Szybkobiegaczek chciał wpisać do kalendarza: ,porządkowanie leśnego stadionu nad źródełkiem”. Inni też mieli wiele pomysłów, a wszystko nagle wydawało im się najpilniejsze. [Grabowski 2016: 6-8].

$\mathrm{W}$ podanym powyżej fragmencie, tak jak i w baśniach ludowych, nie obowiązuje „zasada logicznego myślenia w sprawach podstawowych, zasada tożsamości rzeczy (...) wszystko może być nie tylko tym, czy jest, ale również jednocześnie czymś zupełnie odmiennym" [Pawluczuk 1978: 291-292]. Opowieść uwrażliwia na kulturowe znaczenia, a zarazem pozwala podążać za przygodami baśniowego skrzata strukturą języka literatury pięknej, który wymaga uwagi i znajomości zaawansowanego słownictwa związanego z polską przyrodą. Konteksty kultury ludowej przedstawione w literaturze dziecięcej to kolejny element edukacji polonijnej.

W Kirkcaldy polska muzyka i piosenki odgrywały szczególnie ważną rolę we wprowadzaniu podczas zajęć wiedzy o regionach. Za przykłady niech posłużą piosenki „Stokrotka” - lekcja o nadchodzącej wiośnie i polskiej przyrodzie, „Płynie Wisła” - lekcja o Krakowie i jego legendach, „Góralu, czy ci nie żal” - lekcja o życiu mieszkańców Podhala i Zakopanego, „W zieleni łąka majowa” - lekcja o Dniu Matki, ale i o zwierzętach w Polsce. I w końcu, „Auld Lang Syne” - szkocka piosenka o przyjaźni wykonywana podczas głównych świąt, której znajomość podkreślała charakter polskiej szkoły sobotniej, gdzie poza nauką o języku i kulturze ważne jest utrwalanie wiedzy na temat obecności Polaków w Szkocji, ich roli w szkockim społeczeństwie, a także budowanie relacji z mieszkańcami Szkocji.

\section{ZAKOŃCZENIE}

Kreowanie polskiej kultury i tworzenie środowiska do nauki języka w szkołach sobotnich wymaga zaangażowania i wysiłku zarówno nauczycieli, jak i rodziców oraz uczniów. W artykule podkreślam, iż nauczanie języka, kultury, historii oznacza umieszczanie dzieci przez kilka dni w tygodniu w kontekście doświadczenia etnograficznego kraju, z którego pochodzą ich rodzice ${ }^{7}$. Metody edukacyjne wykorzystane jako standardowe techniki nauczania równoważą różnicę między szkockim a polskim systemem edukacji, tworząc strukturę dla kulturowego zanurzenia

${ }^{7}$ Wpływ brytyjskiego środowiska kulturowego sprawia, że otrzymujemy niejako podwójną osobowość, którą określa np. niestałość naszego dotychczasowego imienia i nazwiska zarówno w mowie, jak i piśmie, co np. widoczne w użyciu form: Anna - Ann, Anne, Ana; Sznajder - Schneider, Schnaider, Schnider, Shnider. Oczywiście w języku polskim także „polonizuje się" obcokrajowców, np. w rodzinach wietnamskich w Krakowie dzieci otrzymują podwójne polskie i wietnamskie imiona, np. Monika Li Truong, co ułatwia im asymilację w szkole. 
się w język. Autentyczne momenty uczenia się języka dziedziczonego w domach są poszerzone o szkołę sobotnią, włączając w to doświadczenie kulturowej wspólnoty, językowej poprawności i językowego dostosowania się do kontekstu, możliwość komunikowania się z innymi członkami polskiej diaspory. Zdolności dwujęzyczne u dzieci rozwijają się także dzięki inicjatywom społeczności zmierzającym do integracji z międzynarodową i wielokulturową Szkocją, jednocześnie podkreślając przy tym własną odrębność językową i tradycję, które stają się powodem do dumy. Badanie charakteru edukacji małych Szkotów pochodzenia polskiego (Polish Scottish) ukazuje również konieczność dialogu z kulturą szkocką i potrzebę włączania w naukę języka elementów szkockiej etnografii.

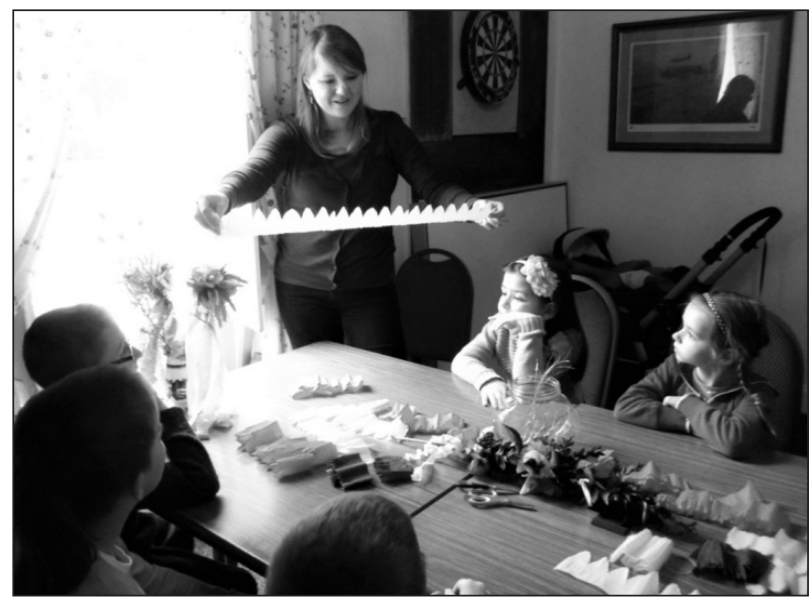

ZDJęCIE 1. Warsztaty na temat Palm WielKanocnych Z etNografKą Dorotą NiczKe,

2012 R. INSTRUKCJA WYKONANIA KWIATKA Z BIBUŁKI DEKORUJĄCEGO PALMĘ

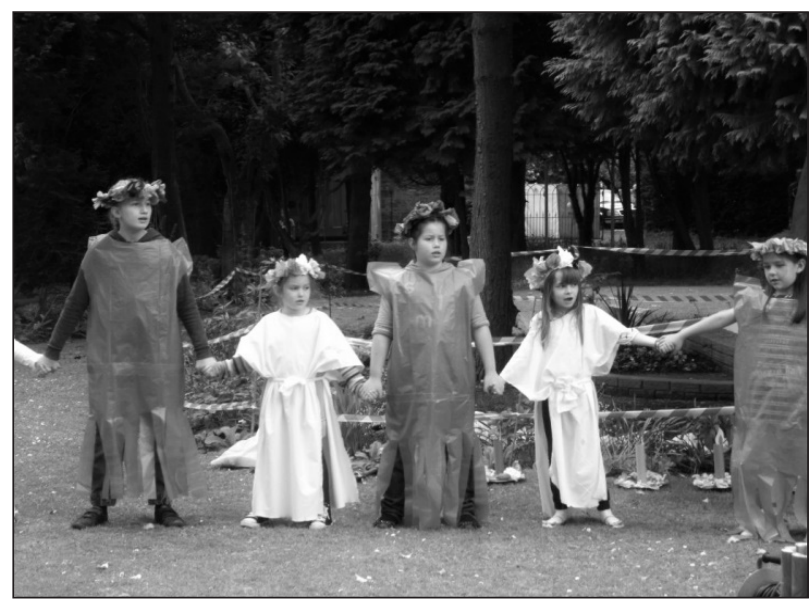

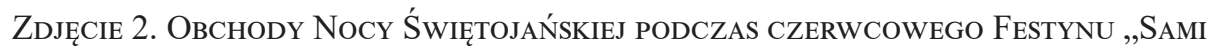
SWOI” w 2012 R. WSPÓLNY TANIEC PRZEDSZKOLAKÓW I UCZNIÓW W KRĘGU WOKÓŁ OGNISKA. ZA DZIEĆMI WIDOCZNE PAPIEROWE WIANUSZKI ZE ŚWIECAMI 


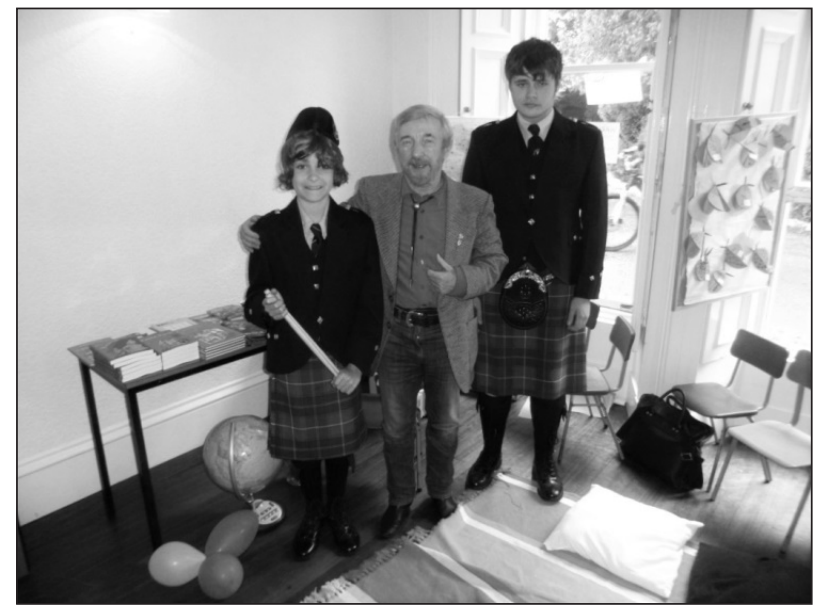

ZdJęCIE 3. PisArZ I POETA ANDRZEJ GRABOWSKi PODCZAS PROMOCJI BAŚNI „PRZYGOdy SKrZATA WiercipiętKa” w 2012 R., FeSTYN „SAMi SwOI” W KirkCALdy

\section{BibLiOgRafia}

Anzulewicz N. [2014], Strategia realizacji potrzeb edukacyjnych w Polskich Szkotach Sobotnich w Wielkiej Brytanii, [w:] Od wielokulturowości miejsca do międzykulturowości relacji społecznych. Wspótczesne strategie kreowania przestrzeni życia jednostki, Nikitorowicz J., Muszyńska J., Boćwińska-Kiluk B. (red.), Wydawnictwo Akademickie Żak, Warszawa, s. 250-266.

Bobiński W. [2004], Konteksty kulturowe w dydaktyce literatury, [w:] Polonista w szkole. Podstawy ksztatcenia nauczyciela polonisty, Janus-Sitarz A. (red.), Wydawnictwo Universitas, Kraków, s. 217-237.

Bukalska P. [2016], Nikt nie chciatby wracać, „Tygodnik Powszechny”, nr 27, s. $12-13$.

Bukraba-Rylska I. [2002], Kultura ludowa - wieś - mieszkańcy wsi, Instytut Rozwoju Wsi i Rolnictwa PAN, Warszawa.

Chin N.B., Wigglesworth G. [2007], Bilingualism. An advanced resource book, Routledge, Londyn-Nowy Jork.

Fatyga B. [2014], Nieład pojęciowy a program wspierania kultury ludowej przez MkiDN, [w:] Kultura ludowa. Teorie - Praktyki-Polityki, Fatyga B., Michalski R. (red.) Instytut Stosowanych Nauk Społecznych, Warszawa, s. 407-433.

Grabowski A. [2016], Przygody Skrzata Wiercipiętka, Wydawnictwo Skrzat, Kraków. Ludowe Okulary. Miniprzewodnik dla dzieci po kulturze i sztuce ludowej [2016], www.ludowaakademia.pl [dostęp: 4.03.2016].

Martowicz A. [2014], Dwujęzyczność w pytaniach i odpowiedziach, Association for the Promotion of Polish Language Abroad, Edynburg. 
Martowicz A., Roach A. [2014], Polish Language Learning in Scotland: Key facts and opportunities, Cross-Party Group on Poland at the Scottish Parliament, Education Subcommittee, Edynburg.

Mokras-Grabowska J. [2013], Zasoby kultury ludowej jako komponent przestrzeni turystycznej, „Turyzm”, nr 23, s. 47-53.

Moskal M. [2010], Polish migrant children's experiences of schooling and homeschool relations in Scotland, www.ces.ed.ac.uk/PDF\%20Files/Brief054.pdf [dostęp: 21.10.2016].

Moskal M. [2016], Language and cultural capital in school experience of Polish children in Scotland, "Race, Ethnicity and Education", nr 19, s. 141-160.

Niematerialne dziedzictwo kulturowe [2016], Narodowy Instytut Dziedzictwa, Warszawa, niematerialne.nid.pl [dostęp: 25.07.2016].

Nott-Bower A. [2016], Dwujęzyczność a rozwój dziecka. Zalety i wyzwania dwujęzyczności, „Konferencja nauczycieli Polskich Szkół Sobotnich Londyn, 9 lipca 2016”, Polska Macierz Szkolna.

Pawluczuk W. [1978], Perspektywy kultury ludowej, [w:] Teoria kultury. Folklor a kultura, Waliński M. (red.), Uniwersytet Śląski, Katowice, s. 284-317.

Piętka-Nykaza E., McGhee D. [2014], Polish migrants in Scotland: voting behaviours and engagement in the Scottish independence referendum, ESRC Centre for Population Change. www.cpc.ac.uk/publications/cpc_briefing_papers/pdf/ BP20_Polish_migrants_in_Scotland.pdf [dostęp: 22.12.2015].

Polska Macierz Szkolna [2016], http://www.polskamacierz.org/proces-nauczania/ materialy-konferencyjne-dla-nauczycieli-2/ [dostęp: 29.10.2016].

Polska Szkoła [2016], http://polskaszkolakirkcaldy.org (dostęp: 15.10.2016).

Polish Language to be Included in Edinburgh School Curriculum Soon [2015], www.daytranslations.com [dostęp: 8.01.2015].

Roter-Bourkane A. [2015], Polski folklor w nauczaniu języka i kultury polskiej. Historia, stan obecny, perspektywy, Międzynarodowa Konferencja „O lepsze jutro studiów polonistycznych na świecie", Uniwersytet Jagielloński, Kraków.

Sołtan K. [2012], Etnolog - zaloguj się na ludowo. Materiaty dla nauczycieli, http:// www.mazowieckieobserwatorium.pl/media/_mik/files/4462/etnologpublikacja1.pdf [dostęp: 29.10.2016].

Stochnioł H. [2015], Rola rodziców i opiekunów w wychowaniu $w$ warunkach wspótczesnej migracji, Zechenter K. (red.), Po polsku na Wyspach. Poradnik dla rodziców dzieci dwujęzycznych. A guide for parents of bilingual children, Polski Uniwersytet na Obczyźnie, Londyn, s. 39-61.

Sznajder A. [2013], Z koronka przez świat. Praktykowanie rękodzieła ludowego wśród polskiej emigracji w Szkocji, „Twórczość Ludowa”, nr 27, s. 66-67.

Sztych D. [2008], Zwierzęta gospodarskie w polskiej kulturze ludowej, „Wiadomości Zootechniczne", nr 46, s. 39-47. 
Wspólnota Polska [2016], http://odnswp.p1/ [dostęp: 29.10.2016].

Zechenter K. [2015], Dwujęzyczność przez zabawę czyli jak uczyć języka polskiego poza polska szkoła, [w:] Po polsku na Wyspach. Poradnik dla rodziców dzieci dwujęzycznych. A guide for parents of bilingual children, Zechenter K. (red.), Polski Uniwersytet na Obczyźnie, Londyn, s. 85-107.

Z Wiejskiego Ogródka [2016], www.zwiejskiegoogrodka.wordpress.com [dostęp: 4.03.2016].

http://www.polskamacierz.org/wp-content/uploads/2014/08/Dwuj\%C4\%99zyczno $\%$ C5\%9B $\% \mathrm{C} 4 \% 87$-a-rozw $\% \mathrm{C} 3 \% \mathrm{~B} 3 \mathrm{j}$-dziecka-zalety-i-wyzwania-dwuj\%C 4\%99zyczno\%C5\%9Bci-macierz.pdf [dostęp: 21.10.2016]. 